Asian J. Med. Biol. Res. 2020, 6 (2), 244-254; doi: 10.3329/ajmbr.v6i2.48056

\author{
Asian Journal of \\ Medical and Biological Research \\ ISSN 2411-4472 (Print) 2412-5571 (Online) \\ www.ebupress.com/journal/ajmbr
}

\title{
Article \\ Impact of beel encroachment on aquatic biodiversity and vulnerability of poor fishermen in Noagaon District, Bangladesh
}

\author{
M. A. Salam ${ }^{1 *}$, K. M. Shakil Rana ${ }^{1}$ and Md. Touhidur Rahman ${ }^{2}$ \\ ${ }^{1}$ Department of Aquaculture, Faculty of Fisheries, Bangladesh Agricultural University, Mymensingh-2202, \\ Bangladesh \\ ${ }^{2}$ Department of Fisheries, Bangladesh
}

${ }^{*}$ Corresponding author: Professor Dr. M. A. Salam, Department of Aquaculture, Bangladesh Agricultural University, Mymensingh-2202, Bangladesh. Phone: +8801711024408; E-mail: salamaqua@bau.edu.bd

Received: 15 May 2020/Accepted: 21 June 2020/ Published: 30 June 2020

\begin{abstract}
Natural water bodies in Bangladesh are under threat of encroachment due to high population pressure, overexploitation, change of watercourses, and siltation. Therefore, the present study carried out to assess the degree of encroachment of floodplains and its impact on fish biodiversity and the livelihoods of the neighboring fishing communities. The study covered three beels of Naogaon district through remote sensing image interpretation and PRA techniques. The study used three dates remote sensing images and field data which supplemented with the secondary data from diverse origins. Data collected through the recalling method, personal interview with a structured questionnaire and livelihood analysis of fishermen and non-fishermen group living around the beels. The data interpretation showed the water area reduced by $80 \%$ from 1981 to 2016 in dry season that converted to boro rice cultivation gradually over time. The type of fishing gears and their use also changed radically over time in all the three beels. The fish catch increased steadily from 1981 and reached its peak in 1996, and then started to fall and continued up to 2016 in all the three beels. The study identified thirty species of SIS and SRS in 1981 that were gradually reduced to 6, 8 and 9 in Digholi, Fatepur and Pakuria beels respectively in 2016. Fish biodiversity reduced as fish-friendly large mesh cotton net replaced by the smaller mesh jagotber jal and monofilament synthetic current jal. Moreover, the annual income of the fishermen family was lower than non- fishermen family in beels areas. The current study clearly identified significant encroachment of floodplains area by agricultural activities between 1981 and 2016 and aquatic biodiversity reduced dramatically and the livelihoods of poor fishermen became vulnerable.
\end{abstract}

Keywords: fish biodiversity; beel encroachment; fishermen; livelihood; GIS; remote sensing

\section{Introduction}

Bangladesh is a densely populated country with an area of $147,570 \mathrm{~km} 2$ and 160 million people (Kirpalani, 2016). It is a deltaic country, crisscrossed by some 250 transboundary rivers (Melissa and Wolf, 2019). The country has extensive water resources in the form of ponds, lakes, canals, rivers, estuaries and natural depressions like Haors (larger natural depressed zone), Baors (abundant river channels) and Beels (smaller and deeper depressed zones) covering a total area of 4.56 million hectares (DoF, 2005; Hossain, 2014). Bangladesh has a diverse aquatic biodiversity in open water including 795 native species of fish and shrimp (260 species freshwater fish, 24 species freshwater prawn, 475 species marine fish and 36 species marine shrimp), 15 species of crabs and 3 species of lobsters (Hossain, 2010; Belton, 2011).

Floodplains are the lifeline of aquatic biodiversity and the sources of wild fish that are the main animal protein source and micronutrients for poor people in the country (Tsai and Ahmed 1997; Hussain, 2010; Craig, 2004; Hussain and Mazid, 2001). These vast natural water resources are also significant for income and livelihood for small farmers and fishermen communities. The small indigenous species (SIS) and self-recruiting 
species (SRS) have a higher amount of essential nutrients than culture-based fish species (Thilsted and Hassan 1993; Kawarazuka and Béné, 2010, 2011, Roos et al., 2007; Belton, 2011). On the other hand, the floodplains are the natural feeding and breeding ground of wild fish, rich in natural aquatic flora and fauna and responsible for maintaining biodiversity in the natural aquatic environment (Hussain, 2010). Earlier, wild fish were the major source of animal protein, particularly to the rural people and poor fishermen in the country. Almost $60 \%$ of freshwater fish species are dependent on the floodplain (Boyce, 1991; Belton, 2011). In the 1960s, capture fisheries from the inland water bodies contributed about $90 \%$ of the country's total fish production. However, the fish production from the capture fisheries declined considerably over the years and in 2010-11 that accounted for about $42 \%$. During the era, fish production from inland capture fisheries was almost 20 times higher than the aquaculture production in the country (Hossain, 2014).

The flood controlling embankments, infrastructures, modern agricultural technologies and construction of road networks in last four decades damaged the ecology of floodplains remarkably (Khan, 1993; Ali, 1991). Moreover, the ever-increasing population upsurge the pressure on land in developing countries that make the demand for land which influenced to break the law of land encroachment (Choudhury, 2015; Döös, 2002). In addition, the wetlands in the country shrunk and the linkages between the wetlands and the rivers are disconnected due to the developmental activities (SPARSO, 1984) which are the most suitable spawning, nursing and feeding ground of many freshwater wild fishes (Hussain and Mazid, 2001). However, the illegal intrusion and encroachment of natural water bodies reduced floodplains drastically. The wetlands have also been degraded through the leasing to rice farming which leads to a decline in the aquatic flora and fauna due to the use of agrochemicals to the crops in floodplains (Ali, 1989). Therefore, the present investigation was to see the degree of encroachment of beels in the Naogaon district and its peripheral areas and to measure the actual area of encroached so that, the Government could take appropriate initiatives to protect the illegal encroachment as well as manage the environmental conditions in a sustainable way.

\section{Materials and Methods}

\subsection{Approaches and methods of the study}

The study was designed to assess the impact of agricultural encroachment on the livelihoods of fishermen based around the three beels in Naogaon Sadar upazila of Naogaon district, Bangladesh. The major task was to analyses the trends of agricultural encroachment over the years, changes in water areas for 30 to 35 years to the present time in the beels, changes in livelihoods of the fishermen, adoption of alternate livelihoods and institutional context in relation to the sustainable livelihoods.

The study conducted on two different methods such as Remote Sensing (RS) image interpretation and Participatory Rural Appraisal (PRA). Remote Sensing (RS) image interpretation carried out following Salam (2007) method which is supported by the secondary data collected from a range of sources like field visits, literature review, internet search and consultation with the relevant reports. Primary data collected by livelihood analysis through PRA and FGD method and interviews with the individual stakeholders. Information collected using FGD at the household level through a structural questionnaire interview. The complete method for the study presented in Figure 2 and the details are as follows: Multi-temporal Thematic Mapper image data obtained from Landsat-5 and Landsat-7 launched by NASA, USA was used (Table 1). Landsat TM/ETM image has 7 bands with 3 visible and 4 infrared channels including one thermal band. The spatial resolution of one pixel of TM image is $30 \mathrm{~m}$ by $30 \mathrm{~m}$ except for thermal band with $120 \mathrm{~m}$ by $120 \mathrm{~m}$.

\subsection{Study area}

The three existing beels of Sadar Upazila of Naogaon district selected for the assessment, located at the $24^{\circ} 42^{\prime}$ to $24^{\circ} 56^{\prime}$ north latitudes and $88^{\circ} 48^{\prime}$ to $89^{\circ} 00^{\prime}$ east longitudes (Figure 1). The main rivers in this Upazila are Little Jamuna and Tulsi Ganga. Land uses are single crop 41\%, double-crop 47\% and triple crop rest 12\%. The main crops in area are paddy, wheat, potato, brinjal, patal, onions, garlic, and pulses. The Digholi Beel located on the south-west corner of Naogaon district town, which was a large wetland having more than 200 hectares of water area about 100 years ago. Two narrow canals crisscrossed the beel, which have only 44-hectares to the public. Moreover, the Jamuni Fatepur Beel, located on the south-west corner of Naogaon town, of 20 kilometers away from the Sadar Upazila headquarters. Once, this Beel was a large wetland having 200 hectares' land but currently reduced to 62.21 hectares. About three hundred seventy fishermen households live in the adjacent villages. By contrast, the Pakuria Patiladoho Beel located on the south from the Naogaon town about 15 kilometers from the Sadar Upazila headquarter. Previously this floodplain was of 129-hectare, now shrieked to 14.4 hectare, which is fully public property. The Beel is partially encroached by the agricultural cropland and has a few illegal ponds. These villages have about 200 fishermen households. 


\subsection{GIS based image processing}

The image-processing carried out in the Geographical Information System (GIS) laboratory, Department of Aquaculture, Faculty of Fisheries, Bangladesh Agricultural University (BAU), Mymensingh, Bangladesh. The Remote Sensing (RS) satellite images integrated into the GIS database (Figure 2). The satellite images collected from the Global Land Cover facilities of Maryland University, USA. The Landsat TM/ETM images used in this study are from the Path of 138, and Row of 43 which obtained on 09 February 1977, 11 November 1989, and 17 November 2000 (Table 1). The collected image covered an area of the western and middle parts of Bangladesh along with the part of two large rivers the Padma and the Jamuna. The Landsat TM/ETM image has 7 bands with 3 visible and 4 infrared channels including one thermal band. The spatial resolution of one pixel of TM/ETM image is $30 \mathrm{~m} \times 30 \mathrm{~m}$ except for the thermal band $120 \mathrm{~m} \times 120 \mathrm{~m}$.

\subsection{Data processing and software used in the study}

IDRISI KILIMANJARO, the GIS and image processing software used for Landsat satellite image processing in this study which developed by the Graduate School of Geography at Clark University, Worcester, MA, USA. Moreover, the vector based ArcGIS Desktop 10 GIS software used to edit and digitize the map boundary to separate the area of interest from the RS image. Paint Shop Pro 10, a raster-format image editing software also used for image processing and editing purposes. The manipulated and edited images imported in to IDRISI KILIMANJARO GIS software and resampling of the images done in the IDRISI environment to bring all the images in a single reference system.

The images enhanced digitally to enable their visual interpretation. The false-color composite (FCC) images produced for visual analysis with the bands of 432 for Landsat 2 (TM) of 1977 and 347 for Landsat 5 (TM) and Landsat 7 (ETM) of 1989 and 2000 images, respectively. An associated contrast stretch of 5\% applied to give a better visual representation (Ameen, 2018; Kay and Hick, 1988). The Landsat TM bands 4, 3 , and 2 (near-infrared, visible red and visible green respectively) and 3, 4, and 7 (near-infrared, visible red and infrared respectively) used for FCC visual discrimination of water and non-water boundary. Initially, with the help of LGED map and images a subset window of the study area was defined and extracted using the WINDOW option in IDRISI KILIMANJARO. The window for the study covered an area of 25,208 hectares of land mass. Following the WINDOW creation, the boundary of the Naogaon Sadar Upazila overlaid as mask to the FCC images to eliminate the outside areas other than the Naogaon Sadar Upazila from the WINDOW.

\subsection{Unsupervised image classification}

The unsupervised image classification carried out using the CLUSTER module which groups together the features with similar reflectance patterns in a certain land use category. The module used to produce an unsupervised classified image from the image bands of 4, 3 and 2 for 1977 image and 3, 4, and 7 for 1989 and 2000 images which provided the number of spectral classes in the raw data (Figure 2). CLUSTER module automatically classified the images into distinct 15 fine clusters categories. After cluster operation, a 3 x 3 mode FILTER applied to whip out the small clusters less than 9 pixels. The clusters were then classified based on the color composite Landsat TM/ETM images and field data and reclassified into four land cover classes.

\subsection{Field based data collection}

The field-based primary data collected and supported the secondary data, image classification, and interpretation, and quantitative and qualitative analysis carried out. Primary data collected through PRA tools and interviewing individuals with a developed questionnaire, field observation, the experience of fishers, and comments from the community leaders. The secondary data collected from official records and published documents (Figure 3). A set of questionnaire developed after discussing with the stakeholders in the study area. The livelihood status of fishermen and non-fishermen groups emphasized during questionnaire preparation. The draft questionnaire pre-tested and finalized with the feedback from key informants and sample farmers in the beel areas. Finally, the questionnaire survey completed carefully with randomly selected 30 fishermen and nonfishermen group total 60 from each beel. Some key factors like age group, educational qualification, financial and social status, location of the village and involvement in the resource uses considered during sample selection. In addition, the focus group discussion (FGD) carried out to collect some facts which not included in the individual questionnaire interview, such as trend and change analysis. The FGD carried out in 9 villages, 3 at each beel and target group was the fishermen and crop farmer groups. In each FGD session, 8-12 persons of different age group attended. The village, where good number of fishermen lived, selected for FGD. The villagers selected on random basis for PRA and FGD works, whereas, aged persons selected for historical trend analysis. The FGD session contained the discussion on 35 years' history of beel and fishermen's and non- 
fishermen's livelihood. The participants recalled the facts from 1981 to 2006 at five years' interval as 1981 , 1986, 1991, 1996, 2001 and 2006. The data collected in the above methods crosschecked with the community leaders and key informants in the areas. The DoF staffs, Agricultural extension workers, school teachers and social leaders consulted for cross checking of the data.

\subsection{Data analysis}

All the collected data compiled, transferred into the computer in MS Excel Programme, cross-checked for any mistake and analyzed in MS Excel 2016 version. The indicators in data analysis were area of beels in different years, water holding capacity in different seasons and years, amount of fish and fish species harvested in different period, assets, income and expenditure, social and financial status of fishermen and crop farmers in the beel areas.

\section{Results and Discussion}

\subsection{Image classification and interpretation}

The FCC images of 432 bands for February image of 1977 and 347 bands for mid-November images for 1989 and 2000 were obtained (Figure 4), which was used to guide the land use and land cover classification and images interpretation. In the FCC image of 1977, blue and black represent the water color; by contrast the water color is reddish to brown in 1989 and 2000 FCC images which are the indication of turbid water. In 1977 FCC image bare land was much higher followed by vegetation. The water and rice was minimal as the image was taken in completely dry season and only little bit boro rice was present or other aquatic vegetation may have represented that class. The variation of color in FCC images of 1977, 1989 and 2000 are due to 1977 image was taken from Landsat TM 5 platform which was not that much of high quality images and only three bands were available than the images of 1989 and 2000 which were taken from Landsat ETM 7 platform that quality of images were higher and all the seven bands were accessible. So, in both the images of 1989 and 2000 represented the same land use phenomenon in same color and used for unsupervised classification.

Produced cluster images were further reclassified into four distinct land use categories looking at the topographic map and FCC images such as bare land, vegetation, water bodies and aman rice, (Figure 5). The results obtained through unsupervised classification of the two date images showed that the vegetation and water area were much higher in 1989 image than the image of 2000 (Figures 5 and 6). On the other hand, the extend of bare land and aman rice was less in 1989 image than the 2000 image due to gradual encroachment by the rice farmers from the vicinity of the beels.

From the unsupervised image classification, it is clear that the bare land and aman rice areas have increased 13.54 and $10.31 \%$ in 2000 image than the image of 1989. By contrast, the homestead trees and water areas have decreased in 11.54 and $12.31 \%$ in 2000 image than the image of 1989 (Figure 6). This is due to the water flow has declined almost 60\% since 1973 in the Ganges river and its channel systems which are the major water sources in the area (Mirza, 2002; Salam, 2007). The possible reasons of bare land and aman rice increased and homestead trees and water area decreased could be the reduction in freshwater flow from the upstream (Sarker et al., 1999). Mirza (2002) also mentioned that the construction of the Farakka Barrage in 1973 on the Ganges River by neighbouring country has silted up most of its southbound distributaries in Bangladesh leading to the river systems and impacted the carrying capacities of these rivers. As a result, the dry season as well as the wet season water flow in many of the rivers was either cut off or substantially reduced, lowering the ground water level causing ecological devastation, as well as desertification in northern part (Islam et al., 2010).

\subsection{Change of cropland area in the beels}

The crop cultivation was practiced in all the studied beels from the ancient time but extend of covering area was varied over the period. In the dry season, the water of the beels usually shrunk due to water extraction and evapotranspiration then certain areas surrounding the beels have emerged. These emerged lands used for crop cultivation by the neighbouring land owners. With the population increase, extend of cropping areas and intensity has been increasing year after year and the beels have been decreasing over the time. In the year 1981, the crop land area of three beels were $20 \%$ which have gradually expanded to 87.5, 86.6 and $69.17 \% \%$ in Digholi, Jamuni Fatepur and Pakuria Patiladoho beels respectively in 2006 (Table 2). It was observed that the increased rate of the crop land areas was directly related to the decreased rate of the beel areas in the study area (Rahman, 2015; Rahman, 2017). 


\subsection{Reduction of water areas of three beels in dry season}

In dry season, all of the natural water depression, manmade water holding areas as well as beels, canals, haors, baors has dried out in every year. This is a natural phenomenon. Table 3 showed the gradual shrinking of water areas of the beels from 1981 to 2006. Digholi, Jamuni Fatepur and Pakuria Patiladoho beels had 55, 800 and 225 ha water areas respectively in 1981, which have shrunk to 11, 250 and 140 ha respectively in 2006 (Table 3). Meanwhile, areas of crop land in all three beels have increased gradually throughout the period (Figure 6).

Moreover, the water from the beels are used for agricultural crop production, water drainage to reclaim the land for rice culture that making the fishermen vulnerable to food in secured in the areas, indebtedness, gender discrimination, unemployment, least access to health and education and other government services. The study also revealed that due to gradual agricultural encroachment the floodplain water areas in the beels and fish production were reduced dramatically over the period and the livelihoods of poor fishers became vulnerable. Swarnali, (2017) reported similar trends around Buriganga River in Dhaka district. The floodplains were used for paddy cultivation damaging aquatic vegetation and fish biodiversity (Verhoeven and Setter, 2010). Fishing occupation of fishers was found replaced by other income generating activities. Rahman (2012) reported the fishers were engaged with various Alternative Livelihood Generating Activities to support their families in Nijhum Dwip, Hatiya Upazila, Noakhali District.

Population in Bangladesh increased rapidly from 90 million to 140 million between 1981 and 2006 (BBS, 1981) resulting excessive demand for food and shelter. As a result, croplands have been used for housing and pressure has turned to floodplains for the excess production of crop. Nearly 82,000 ha of land on an average have been lost each year (Rezvi, 2018). Agricultural intensification and increase in irrigated cropland through the conversion of floodplain into agricultural land led to loss of biodiversity. Accordingly, conversion of floodplain into cropland was started to meet the high demand of food without considering the aftermath. In the study area due to 20 to $81 \%$ agricultural land expansion on an average through encroachment of floodplain, water area available for fish and aquatic vegetation was shrunken from 68 to $8 \%$ on an average with noticeable impact on surrounding fishermen during 1981 to 2006. Due to construction of unplanned flood control embankments / dams/ barrages, flow and direction of river has been changed resulting reduction or blockage of water inflow into floodplain. Consequently, water area in the floodplain has been dropped gradually (MPO, 1987; Nishat, 1993), which complies with the findings of the present study.

The expansion of agricultural activities has increased the demand of water for irrigation (Rezvi, 2018). So, continuous withdrawal of water from the floodplain has been taking place for crop production squeezing water area. As a result, along with decreased water area water holding capacity of floodplain has also been decreased (Swapan and Pal, 2017). This scenario was observed in the present study, where water holding capacity of the beels under study was found to decrease from 11 months to 6 months on an average throughout the period.

The present study explains the using of different types of gears by the fishermen adjacent to the three beels from 1981 to 2016. Totally 11 fishing gears have been found to use in the three beels in 1981 resulted from FGD sessions in the fishermen and non-fishermen group. The use of different fishing gears has been changed over times (Sultana and Islam, 2016). In the previous years before 1991 fish friendly gears had been used to harvest the fish. All the nets used before that time had bigger mesh size to catch only the bigger size of fish and all small size fish had been escaped (Sayeed et al., 2014). That conservation was maintained by fishers and at that time only the fishermen caught the fish from open water. But after 1991 destructive fishing gears like current jal and jagotber jal had been introduced and the amount of fish has been reduced by the years after 1991 (Sazedul, 2019). Cast net and push net had been used commonly in all the beels from 1981. Cotton seine net was fish friendly and those were replaced by the synthetic net from 1986 (Potter, 2010). So, the types of gears, nature of fishing and amount of fish catch had been changed over time. The cast and push nets were used by single fisherman, but in some cases two people were engaged in cast net fishing (Sultana, 2016). Bamboo trap was used in Digholi beel up to 2001, because this trap was being used by single fisherman but in a small number. Due to reducing the catch, after 1991 the use of this gear had become less frequent. Alam et al. (1997), Das et al. (2003) and Alam et al. (2009) reported similar trends of fishing in beels in different regions.

Table 1. The Landsat tm/ETM images information used in the study.

\begin{tabular}{|lllll|}
\hline Image Data & Date of satellite over pass & Path -Row & Bands & Season \\
\hline Landsat 2 TM & 09 February 1977 & $138-43$ & 432 & Dry Season \\
\hline Landsat 5 TM & 11 November 1989 & $138-43$ & 347 & Post monsoon \\
\hline Landsat 7 ETM & 17 November 2000 & $138-43$ & 347 & Post monsoon \\
\hline
\end{tabular}


Asian J. Med. Biol. Res. 2020, 6 (2)

Table 2. The crop land area increased in three beels from 1981 to 2006 in Naogaon District.

\begin{tabular}{|llll|}
\hline \multirow{2}{*}{ Years } & \multicolumn{3}{c|}{ Crop land areas increased over time } \\
\cline { 2 - 4 } & Digholi beel (\%) & Jamuni Fatepur beel $\mathbf{( \% )}$ & Pakuria Patiladoho beel (\%) \\
\hline 1981 & 20.00 & 20.00 & 20.00 \\
\hline 1986 & 40.00 & 40.00 & 30.00 \\
\hline 1991 & 54.29 & 50.00 & 47.50 \\
\hline 1996 & 74.29 & 66.25 & 51.25 \\
\hline 2001 & 83.33 & 77.14 & 68.33 \\
\hline 2006 & 87.50 & 86.60 & 69.17 \\
\hline
\end{tabular}

Table 3. Changes of areas in all the three beels from 1981 to 2006.

\begin{tabular}{|c|c|c|c|}
\hline \multirow{2}{*}{ Years } & \multicolumn{3}{|c|}{ Changes of beel areas in Naogaon District } \\
\hline & Digholi beel (ha) & Jamuni Fatepur beel (ha) & Pakuria Patiladoho beel (ha) \\
\hline 1981 & 55 & 800 & 225 \\
\hline 1986 & 48 & 783 & 207 \\
\hline 1991 & 47 & 617 & 200 \\
\hline 1996 & 37 & 417 & 187 \\
\hline 2001 & 18 & 317 & 163 \\
\hline 2006 & 11 & 250 & 140 \\
\hline
\end{tabular}

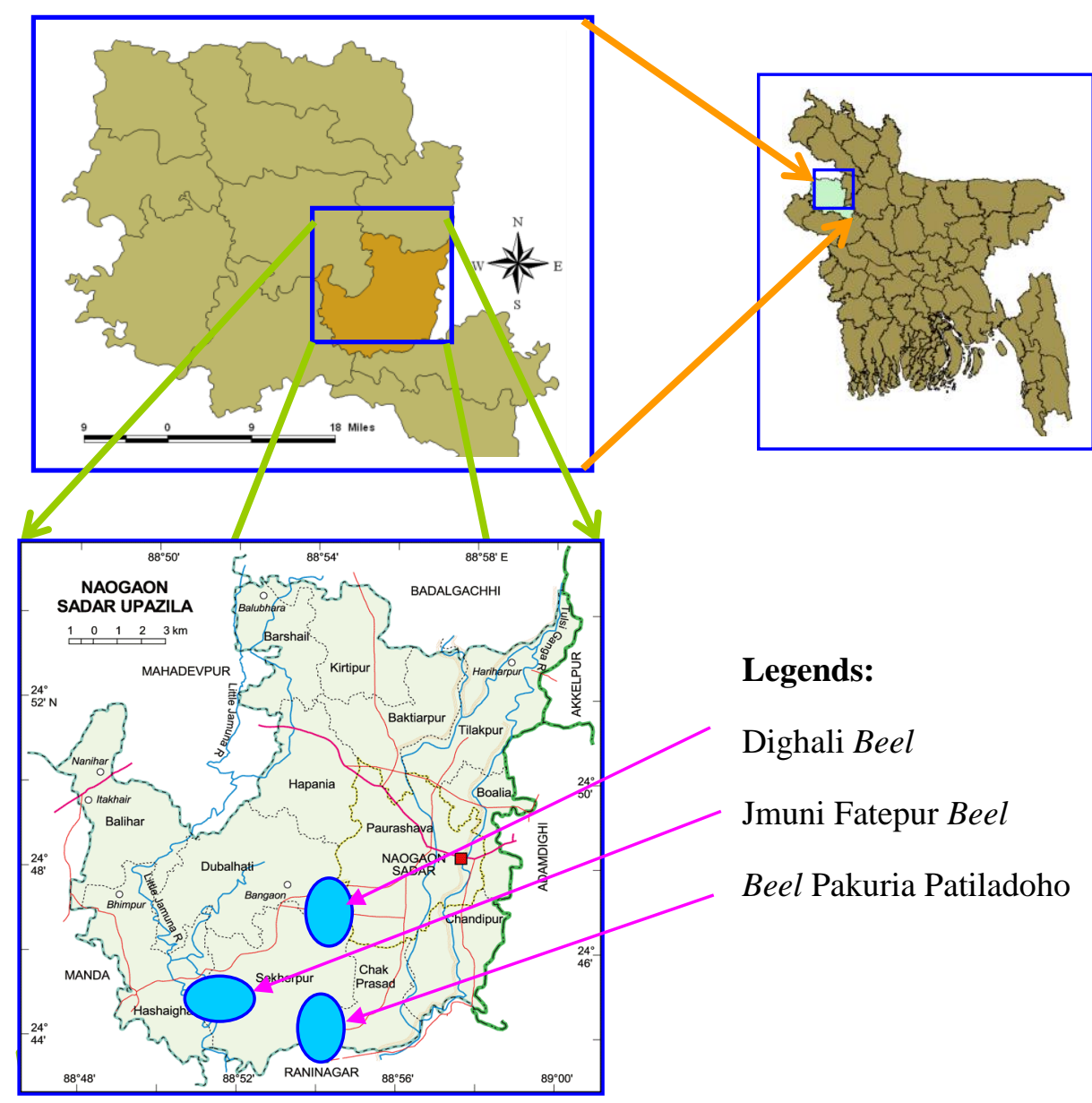

Figure 1. Location of the beels in Sadar Upazila, Naogaon district. 


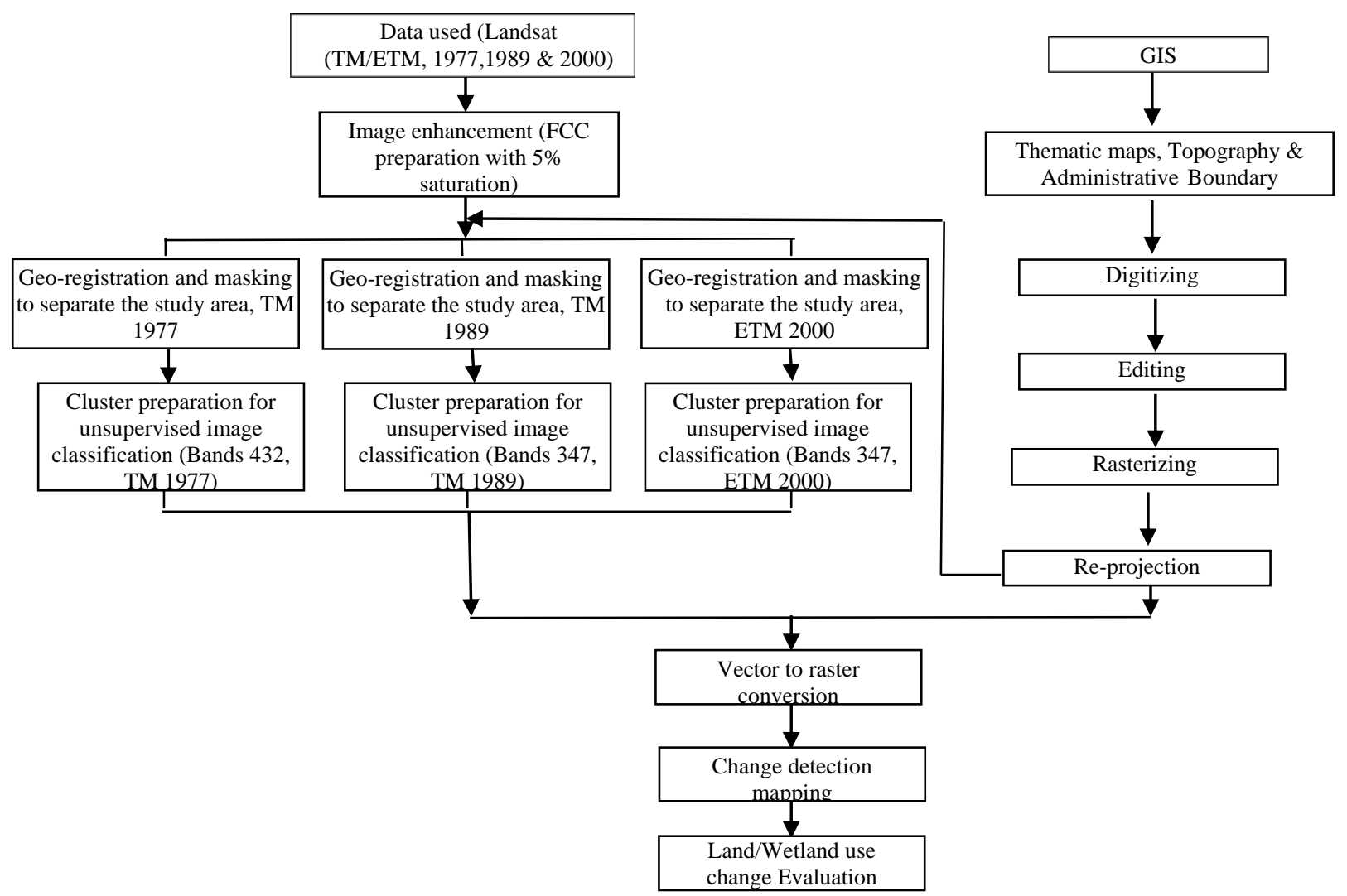

Figure 2. Schematic diagram of the major steps of image processing techniques adopted in the study.

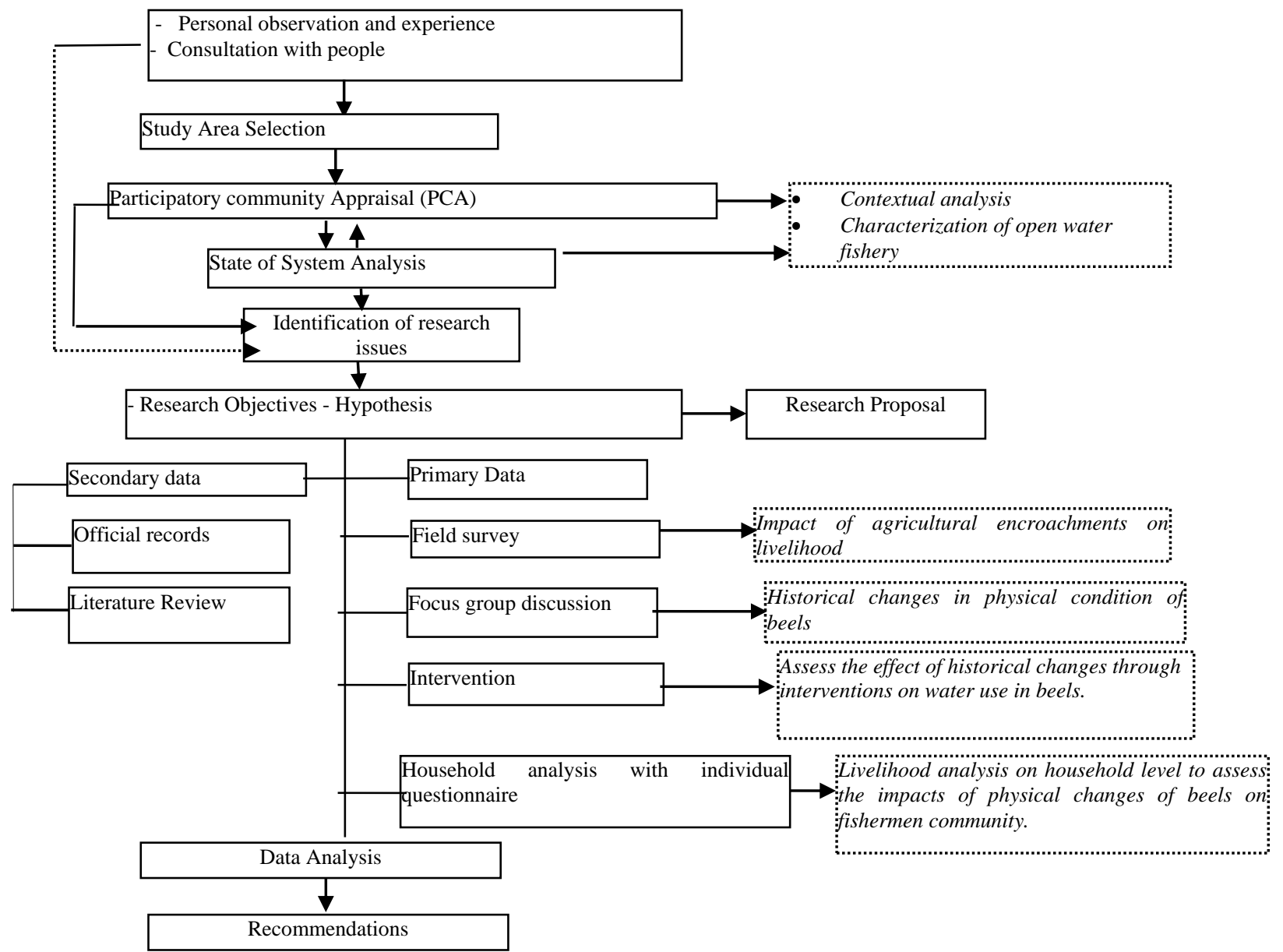

Figure 3. Schematic presentation of research methods (Source: Karim, 2006). 


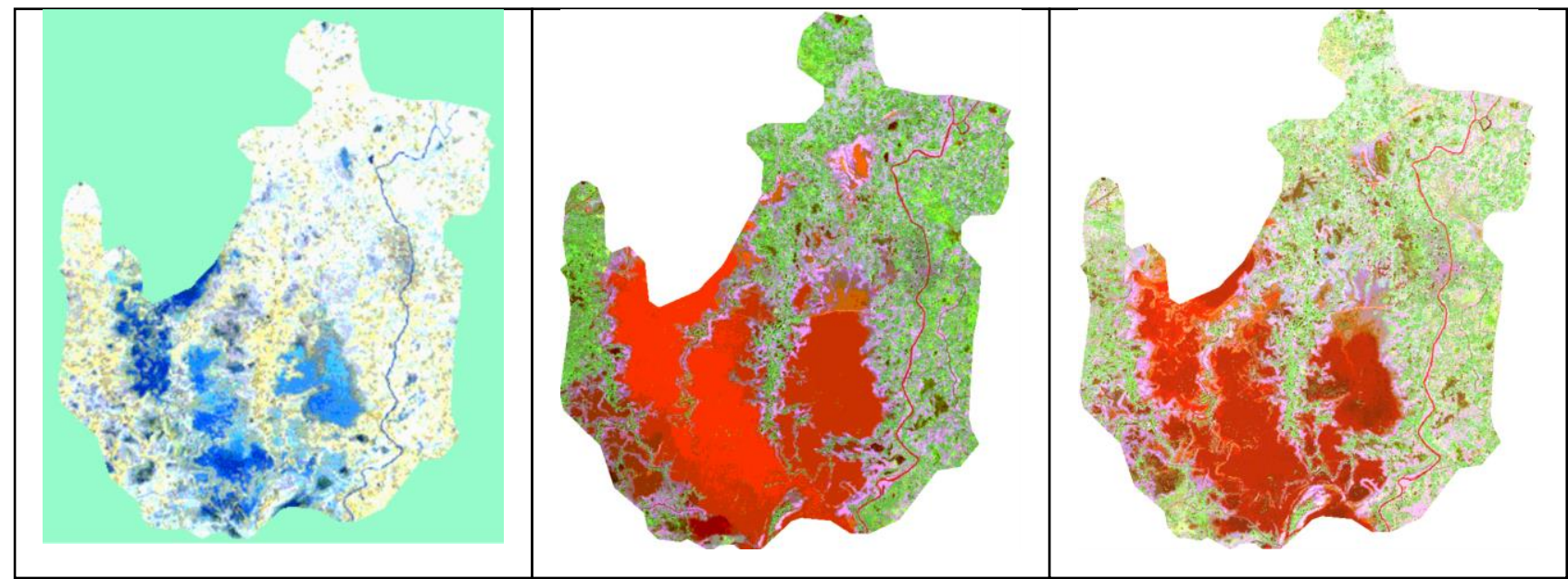

Figure 4. False colour composite (FCC) image of bands 4, 3 and 2 of 1977 and bands 3, 4 and 7 of 1989 and 2000.

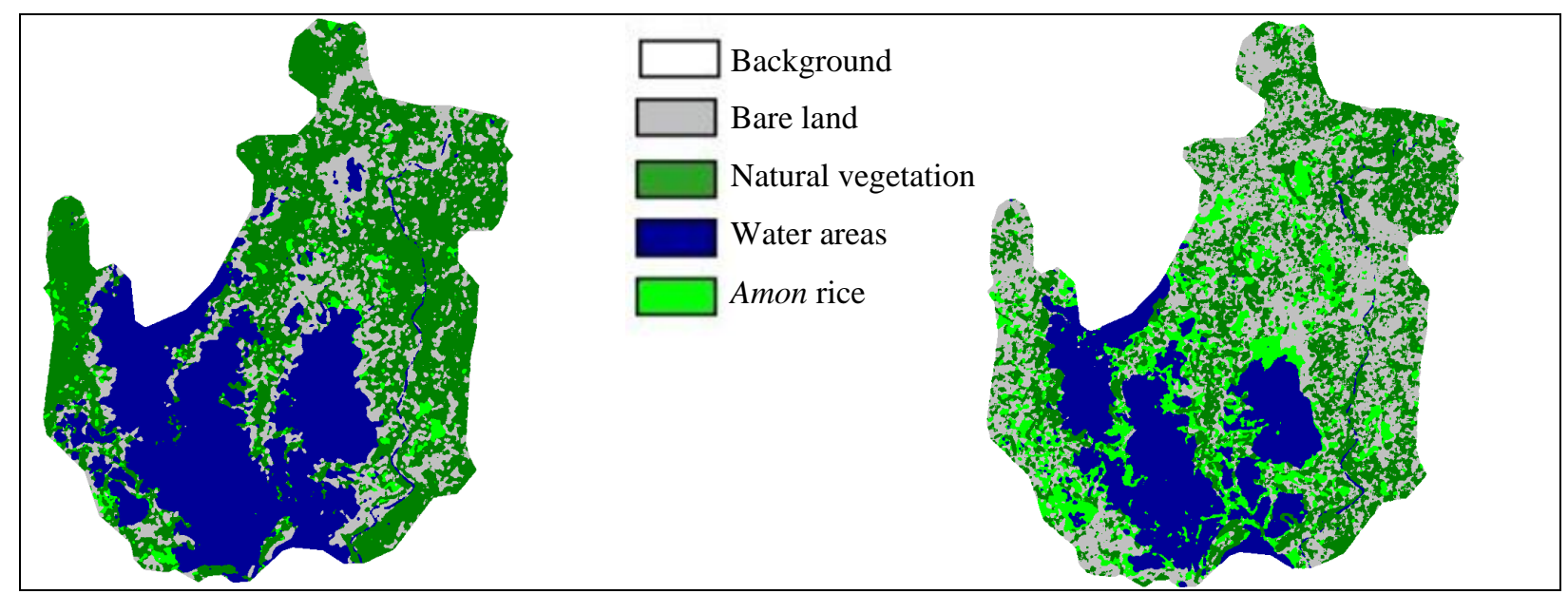

Figure 5. The results obtained through unsupervised classified two date images showed that the vegetation and water areas in 1989 image than the image of 2000.

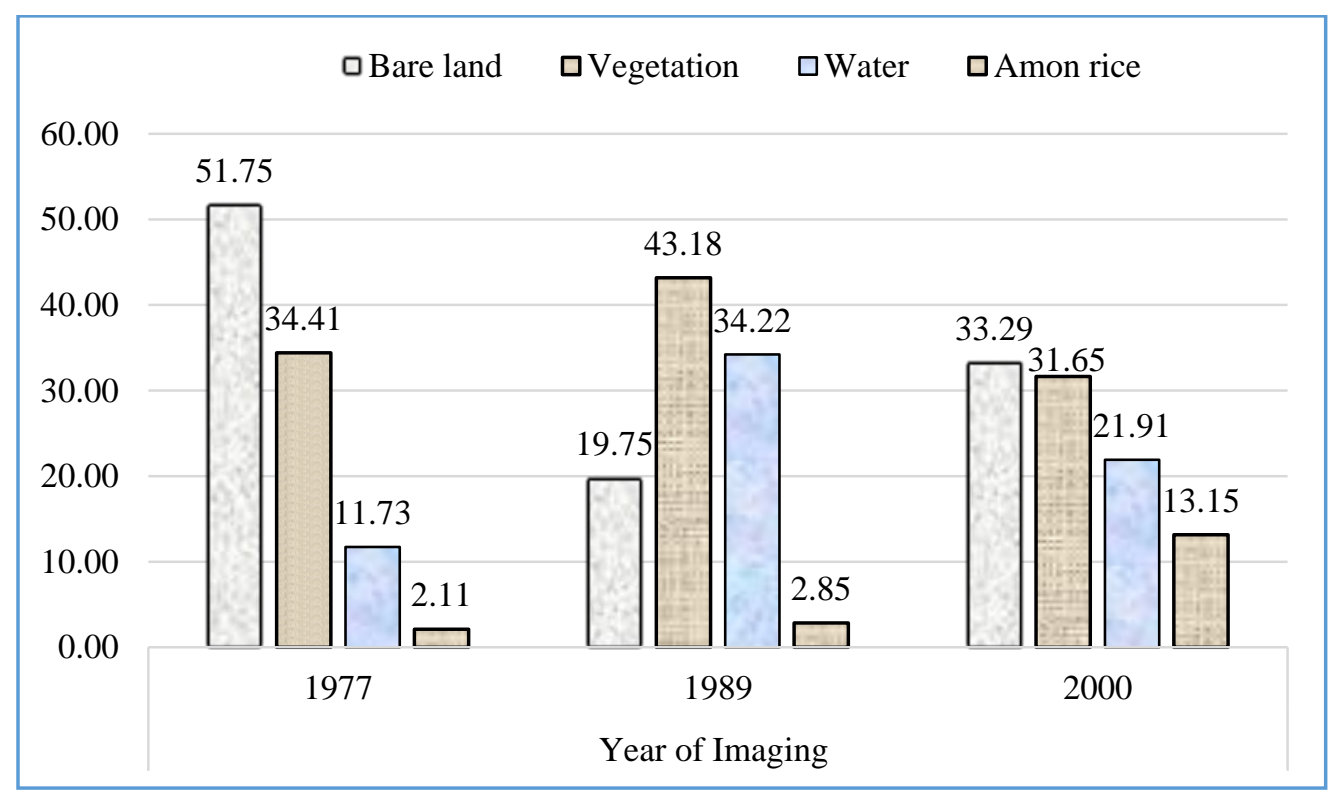

Figure 6. Comparison of various land use types in unsupervised reclassified images of $\mathbf{1 9 8 9}$ and 2000. 


\section{Conclusions}

These floodplains are unique in aquatic biodiversity and availability of diverse aquatic flora and fauna. A large number of fishermen living around the floodplains depend on this resource for their livelihoods. Due to population pressure the floodplains have been encroached in all over the country by agricultural activities. So, this resource base is under great threat, fish biodiversity has been disrupted and the livelihood of fishermen around this resource base has been seriously affected. Hence, the study has concluded with five major findings like (i) encroachment by agricultural activities has done gradually since eights on the floodplains, (ii) fish production has dramatically reduced in the floodplains, (iii) aquatic vegetation in the floodplain has diminished, (iv) livelihood of fishermen around the floodplain has become more vulnerable and (v) fish biodiversity in the floodplain is under great threat.

\section{Acknowledgements}

The authors are thankful for the financial support by Common Wealth Scholarship Commission. The authors also express their gratitude to the staff of Institute of Aquaculture, the Stirling University and Faculty of Fisheries, Bangladesh Agricultural University (BAU), for their support to carry out the research.

\section{Conflict of interest}

None to declare.

\section{References}

Ahmed M, 1997. Socioeconomic and Policy Issues in the Floodplain Fisheries of Bangladesh, chapter 6, In: Tsai, Chu-fa and Ali, M.Youssouf (eds.); Openwater Fisheries of Bangladesh, pp. 89-98.

Alam MS, FA Flowra, MA Salam, AKMA Kabir and H Ali, 2009. Fishing gears, fish marketing and livelihood status of the poor fishermen around the Basantapur beel at Lalpur Upazila. J. Agro. Env., 3: 17-20.

Alam SS, MY Ali and CF Tsai, 1997. Fishing Gear of Floodplain Fisheries in Bangladesh: A Case Study of Chanda, BSKB and Halti Beels. Openwater Fisheries of Bangladesh, Editors: Chu-fa Tsai and M. Yousouf Ali, Bangladesh Centre for Advanced Studies, The University Press Limited, Dhaka, Bangladesh, pp.137152.

Ali MY, 1989. Environment, conservation and fishery resources in Bangladesh. In: Aguero M, Hoq S, Rahman AKM and Ahmed M (eds.) Inland Fisheries Management in Bangladesh, Department of Fisheries, Dhaka, Bangladesh, Bangladesh Centre for Advanced Studies, Dhaka, Bangladesh and International Centre for Living Aquatic Resources Management, Manila, Philippines. pp.149.

Ali MY, 1991. Towards Sustainable Development Fisheries Resources of Bangladesh, International Union for Conservation of Nature and Natural Resources. In: The World Conservation Union, National Conservation Strategy of Bangladesh and Bangladesh Agricultural Research Council, pp. 96.

Ameen ZA, 2018. Contrast enhancement for color images using an adjustable contrast stretching technique. Int. J. Comput., 17: 74-80.

Belton B, M Karim, S Thilsted, KME Jahan, W Collis and M Phillips, 2011. Review of aquaculture and fish consumption in Bangladesh. Studies and Reviews-53. The WorldFish Center.

Boyce JK, 1991. Birth of a mega project, the political economy of flood control in Bangladesh. Bangladesh J. Soc. Stud., 52: 11-23.

Craig JF, AS Halls, JJF Barr and CW Bean, 2004. The Bangladesh floodplain fisheries. Fish. Res., 66: 271-286.

Das T, K Das, N Dutta and A Gupta, 2003. Status of capture fishery in river Barak, Assam, India. The Second International Symposium on the management of large rivers for fisheries, 11-14 February, 2003, Phnom Penh, Cambodia.

Dontree S, 2003. Land use dynamics from multi temporal remotely-sensed data: a case study Northern Thailand, proceedings of the First RS and GIS Conference, Kuwait. pp. 59-67.

Döös BR, 2002. Population growth and loss of arable land. Glob. Environ. Change., 12: 303-311.

Etter A, C Mc Alpine, K Wilson, S Phinn and H Possingham, 2006. Regional pattern of agricultural land use and deforestation in Colombia. Agricul. Ecos. Env., 114: 369-386.

Giri C and S Shrestha, 1996. Land cover mapping and monitoring from NOAA AVHRR data in Bangladesh. Int. J. Remote Sens., 17: 2749-2759.

Hossain M, M Nahiduzzaman, MA Sayeed, E Azim, MA Wahab and PG Olin, 2009. The Chalan beel in Bangladesh: Habitat and biodiversity degradation, and implications for future management. Lakes and Reservoirs: Res. Man., 14: 3-19. 
Hossain MAR, 2014. Habitat and fish diversity: Bangladesh perspective. In: Wahab MA, Shah MS, Hossain MAR, Barman BK and Hoq ME (eds.), Advances in Fisheries Research in Bangladesh: I. Proc. of 5th Fisheries Conference \& Research Fair 2012, Bangladesh Agricultural Research Council, Dhaka, Bangladesh Fisheries Research Forum, Dhaka, Bangladesh. pp. 246.

Hossain MAR, 2014. An overview of fisheries sector of Bangladesh. Res. Agric., Livest. Fish., 1: 109-126.

Hussain MG and MA Mazid, 2001. Genetic improvement and conservation of Carps species in Bangladesh, Bangladesh Fisheries Research Institute and International Centre for Living Aquatic Resources Management, Manila, Philippines, pp. 74.

Hussain MG, 2010. Freshwater fishes of Bangladesh: Fisheries, biodiversity and habitat. Aqua. Eco. Health Man., 13: 85-93.

Islam MR, Z Weijuan, Mao Sishuai, EA Egrinya and H Yuegao, 2010. Status of land degradation and desertification in Bangladesh and the role of agro forestry in their control. J. Agricul. Biotech. Eco., 3: 107116.

Kawarazuka and Béné, 2010. Linking small-scale fisheries and aquaculture to household nutritional security: an overview. Food Sec., 2: 343-357.

Kawarazuka and Béné, 2011. The potential role of small fish species in improving micronutrient deficiencies in developing countries: building evidence. Pub. Health Nutri., 14: 1927-1938.

Khan HR, 1993. Water development activities and their impacts on wetlands, In: Nishat A, Hossain Z, Roy MK and A Karim (eds); Freshwater Wetlands in Bangladesh; Issues and Approaches for Management, IUCN, Gland, Switzerland, pp. 283.

Khuda B, A Barkat and J Helali, 1991. Agriculture Development in Bangladesh: A Macro Study on Sustainability Considerations. Dhaka: University Research Corporation (Bangladesh).

Kirpalani S, 2016. Crowded house: analyzing overpopulation and poverty in Bangladesh and Indonesia. Glob. Maj. E. J., 7: 28-37.

Master Plan Organisation, 1987. Fisheries and flood control, drainage and irrigation development; Master Plan Organisation (MPO) Tech. Rep.17, Dhaka, Bangladesh.

Melissa M, and AT Wolf, 2019. Updating the Register of International River Basins of the world. Informa UK Limited, trading as Taylor \& Francis Group.

Mirza MQ, 2002. The Ganges water-sharing treaty: risk analysis of the negotiated discharge. Int. J. Wat., 2: $57-$ 74.

Nishat A, 1993. Freshwater wetlands in Bangladesh: status and issues, In: Nishat A, Z Hossain, MK Roy and A Karim (eds.), Freshwater Wetlands in Bangladesh; issues and approaches for management, IUCN, Gland, Switzerland, pp.283.

Potter T and MG Pawson, 2010. Gill Netting. Lab. Leafl. MAFF Direct. Fish. Res. Lowestoft, pp. 34.

Rahman AKA, 1993. Wetlands and Fisheries, In: Nishat A, Z Hossain, MK Roy and A Karim (eds.), Freshwater Wetlands in Bangladesh; issues and approaches for management, IUCN, Gland, Switzerland. pp. 283.

Rahman AKA, 2005. Freshwater Fishes of Bangladesh ( $2^{\text {nd }}$ ed.) Zoological Society of Bangladesh, Dhaka, Bangladesh. pp. 397.

Rahman M, MF Tazim, SC Dey, AKMS Azam and MR Islam, 2012. Alternative livelihood options of fishermen of Nijhum Dwip under Hatiya Upazila of Noakhali District in Bangladesh. Asian. J. Rur. Develop., 2: 24-31.

Rahman MA, A Shirin, MI Haidar and MWR Majumder, 2017. Present status (Biodiversity and Conservation) of fish at Chalan Beel in Bangladesh. Int. J. Zoo. Stud., 2: 31-37.

Rahman MR, 2015. Causes of biodiversity depletion in Bangladesh and their consequences on ecosystem services. American J. Envir. Prot., 4: 214-236.

Rashid HE, 1991. Geography of Bangladesh, 2nd ed. University Press, Dhaka. pp. 12-76.

Rezvi MR, 2018. The Factors of Declining Agricultural Growth in Bangladesh and Its Impact on Food Security. South Asian J. Soc. Studies Eco., 1: 1-9.

Roos N, MA Wahab, MA Hossain, SH Thilsted and H Shakuntala, 2007. Linking human nutrition and fisheries: incorporating micronutrient-dense, small indigenous fish species in carp polyculture production in Bangladesh. Food Nutr. Bull., 28: 280-293.

Rouse JW, RH Haas, JA Schell, and DW Deering, 1974. Monitoring vegetation systems in the Great Plains with ERTS. Proceeding of $3^{\text {rd }}$ Earth Resources Technology satellite-1 Symposium Greenbelt. NASA SP-351, 3010-3017. 
Sadeque SZ and MA Islam, 1993. Socio-economic characteristics of fresh water Wetlands of Bangladesh, In: Nishat A, Z Hossain, MK Roy and A Karim (eds.), Freshwater Wetlands in Bangladesh; issues and approaches for management, IUCN, Gland, Switzerland. pp.283.

Salam MA, 2007. Environmental and socio-economic disaster due to Farakka Barrage in Bangladesh- a remote sensing and GIS evaluation. J. Agrof. Env., 1: 119-125.

Sarker MM, MM Kamal and K Hassan, 1999. Identifying the morphological changes of a distributary of the Ganges in response to the declining flow using remote sensing. In: The 20th Asian Conference on Remote Sensing (Proceedings), Hong Kong.

Sarker MM, MM Kamal and K Hassan, 1999. Identifying the morphological changes of a distributary of the Ganges in response to the declining flow using remote sensing. In: The 20th Asian Conference on Remote Sensing (Proceedings), Hong Kong.

Sayeed MA, S Hashem, MA Salam and MAR Hossain, 2014. Assessment of Chalan beel ecosystem diversity through remote sensing and geographical information systems. Int. J. Inn. Applied Stud., 7: 2028-9324.

Sazedul MH, MH Mahmudul, MAR Sayed, KD Sukrit and J Niloy, 2019. Efficiency of fishing gears used in the Payra River at Dumki Upozila in Patuakhali District. Int. J. Oceanogr Aquac., 3: 000157.

SPARRSO, 1984. Fisheries resources survey system: FAO/UNDP project in Bangladesh: DP/BGD/79/0152/FI, Space Research and Remote Sensing Organisation, Dhaka, Bangladesh. pp. 57-96.

Sultana A, SK Mazumder and M Kunda, 2016. Fishing gears and crafts used in Payra River, Bangladesh. Euro. J. Applied Sci., 8: 337-346.

Sultana N and MN Islam, 2016. Fishing gears and methods in the Chalan Beel, Bangladesh. J. Fish., 4: 377-384.

Sultana P, 2012. Implications of floodplain aquaculture enclosure. J. Env. Plan. Man., 55:1159-1174.

Swapan T and S Pal, 2017. Impact of dam on inundation regime of flood plain wetland of punarbhaba river basin of barind tract of Indo-Bangladesh. Int. Soil and Water Conser. Res., 5: 109-121.

Swarnali M, FTJ Nourin, A Siddika and TF Khan, 2017. Encroachment of the Buriganga River in Bangladesh. J. Min. Mat. Charact. Eng., 5: 266-273.

Thilsted S and N Hossain, 1993. A comparison of nutritional value of indigenous fish in Bangladesh-the contribution to dietary intake of essential nutrients. The XV International Congress of Nutrition, Adelaide, Australia. pp. 1-12.

Toufique K and R Gregory, 2008. Common Waters and Private Lands: Distributional Impacts of Foodplain Aquaculture in Bangladesh. Food Pol., 33: 587-594.

Toufique KA, 1997. Some Observations on Power and Property Rights in the Inland Fisheries of Bangladesh. World Develop., 25: 457-467.

Toufique KA, 2015. Analysis of Fish Consumption and Poverty in Bangladesh. BIDS-REF Study Series No. 1501.

Tsai CF and L Ali, 1985. Open water fisheries (carp) management programme in Bangladesh. Fish. Info. Bull., 2: $1-51$.

Verhoeven JTA and TL Setter, 2010. Agricultural use of wetlands: opportunities and limitations. Ann. Bot., 105: $155-163$.

Zaman SMH, 1993. Agricultural Development and Sustainability of Wetlands, In: Nishat A, Z Hossain, MK Roy and A Karim (eds.), Freshwater Wetlands in Bangladesh; issues and approaches for management, IUCN, Gland, Switzerland. pp. 283. 